\title{
The Impact Of Audit Committees' Personal Characteristics On Earnings Management: Evidence From China
}

Baolei Qi, Xi'an Jiaotong University, China

Gaoliang Tian, Xi'an Jiaotong University, China

\begin{abstract}
This study investigates the influence of audit committees' personal characteristics on the firm's earnings management behavior using China's publicly traded firms during 2004-2010. Overall, our findings suggest that audit committees' several personal characteristics, such as age, gender, education level, and working experience, are associated with earnings management, which in turn may affect the quality of financial reporting. The results are robust after controlling the size, independence, meeting frequency of audit committee, and other firm specific characteristics. The results are consistent with the predictions based on the Upper Echelons Theory. The contributions to the earnings management literature and implications for regulators and investors are also discussed.
\end{abstract}

Keywords: Upper Echelons Theory; Audit Committees; Personal Characteristics; Earnings Management

\section{INTRODUCTION}

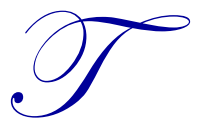

he role of audit committee in ensuring the quality of corporate financial reporting has been emphasized by regulators and scholars since $1999^{1}$. Existing research on board of audit committee have documented that audit committee's size, independence, and meeting frequency can affect the quality of financial report (Klein, 2002; Xie et al., 2003; Abbott et al., 2004; Anderson et al., 2004; Yang and Krishnan, 2005; Lin et al., 2006). Klein (2002) finds that the independence of audit committee is negatively related to earnings management. Xie et al. (2003), Yang and Krishnan (2005) document that the frequency of audit committee meeting is negatively related to current discretionary accruals. Abbott et al. (2004) find the independence and meeting frequency of the audit committee exhibit a significant and negative association with the occurrence of restatement. Anderson et al. (2004) and Lin et al. (2006) find that audit committee size, independence, and meeting frequency are positively related to the quality of corporate financial reporting.

However, little research focuses on the effect of audit committees' personal characteristics on the quality of corporate financial reporting. How do audit committees' personal characteristics, such as age, gender, education level, working experience, affect firm's earnings management behavior?

In this paper, we aim to provide some empirical evidence on the afore-mentioned issue by systematically investigating the associations between several audit committees' personal characteristics as suggested by the Upper Echelons Theory (Hambrick and Mason, 1984) and corporate earnings management behavior. Boards of directors are charged with monitoring and disciplining senior management (Dichev and Skinner, 2002). Dechow et al. (1996) and Klein (2002) investigate the importance of directors monitoring the financial accounting process and find a

\footnotetext{
${ }^{1}$ The Blue Ribbon Commission on Improving the Effectiveness of Corporate Audit Committees (BRC) was formed and it issued a set of recommendations aimed at strengthening the independence and effectiveness of the audit committee (BRC, 1999). In addition, the SEC requires firms to provide disclosures regarding the memberships and activities of their audit committees. Firms are also required to attach a copy of the audit committee's charter and report to proxy statements filed on or after 15 December 2000 (SEC, 1999).
} 
relation between board characteristics and manipulation of accounting information. Boards of directors delegate direct oversight of the financial accounting process to a subcommittee of the full board, the audit committee. Audit committees are responsible for recommending the selection of external auditors to the full board; ensuring the soundness and quality of internal accounting and control practices; and monitoring external auditor independence from senior management. Therefore, audit committees' personal characteristics have the potential to affect firm's earnings management behavior. In this paper, we use modified Jones model (Defond and Jiambalvo, 1994) and performance matched discretionary accrual (Kothari et al., 2005) as the proxies of earnings management. Specifically, we examine the relationships between earnings management and audit committees' personal characteristics such as gender, age, level of education, and working experience.

Using a sample of Chinese A-share listed firms between 2004 and 2009, we run several alternative regressions of earnings management measures on a set of audit committees' personal characteristic proxies and firmspecific control variables. These regression results provide considerable evidence on the relationships between several audit committees' personal characteristics and firm's earnings management behavior. First, the paper finds that female committees are more conservative than male committees, as suggested by the negative relationships between the proportion of female members on audit committee and earnings management. This finding is generally consistent with the literature on gender differences in conservatism and risk-aversion (e.g., Byrnes et al., 1999). Next, audit committees' age is negatively related to earnings management. The results of this paper also indicate that audit committees with financial working background can monitor earnings management better than audit committees without financial working background. This paper does not find significant relationship between audit committees' education level and earnings management.

This paper contributes to the existing literature by investigating audit committee's role in deterring earnings management from a new perspective: audit committees' personal characteristics. Prior research focuses on the relationship between characteristics of audit committee, such as size, independence, and meeting frequency, and earnings management. We provide considerable evidence on the relationships between audit committee's personal inherent characteristics and acquired attributes and firm's earnings management behavior. To the best of our knowledge, this is the first paper to apply the Upper Echelons Theory and study the associations between multiple audit committees' personal characteristics and firm's earnings management behavior.

The results of this paper have implications for investors in understanding the role of audit committees' personal characteristics in deterring firm's earnings management behavior in the context of Chinese emerging capital market and socialist market economy. ${ }^{2}$ Moreover, the findings of this paper may have implications for regulators in promoting financial reporting quality. This paper finds that audit committees with financial working experience vis-à-vis those without such experience are more effectively in monitoring earnings management. Therefore, it may provide evidence to some regulations which require that audit committees include at least one "financial expert" ". Also, the findings suggest the positive role that female audit committees play in achieving greater earnings. This evidence may lend support to legislative or regulatory efforts in many countries to increase proportion of women on the board of directors.

The paper is organized as follows: we review the relevant literature and develop research hypotheses in section 2. Section 3 describes empirical methodologies and provides descriptive statistics. We discuss the empirical results in section 4. Finally, section 5 concludes the paper.

\footnotetext{
${ }^{2}$ More than $70 \%$ of firms listed on Chinese A-shares are state-owned firms. Most of the managers in state-owned firms are appointed by government with a long tenure unless they are found to have committed serious offenses, such as corruption, bribery, embezzlement, etc. Therefore, it is very interesting and meaningful to study the effect of TMT characteristics on their earnings management behavior under the background of Chinese emerging capital markets and socialist market economy.

${ }^{3}$ The Sarbanes-Oxley Act requires that audit committees include at least one "financial expert", and the Chinese Sarbanes Act has the same requirement.
} 


\section{LITERATURE REVIEW AND HYPOTHESIS DEVELOPMENT}

\subsection{Effects of Management and Board Characteristics}

Psychology and management literature has documented that significant personal characteristics-based differences exist in leadership styles, communicative skills, conservatism, risk averseness, and decision-making. Given these differences and their potential implications for corporate governance, the issue of management characteristics has begun to receive increasing attention in corporate finance and corporate governance literature. A body of research has recently studied the impact of management and corporate governance characteristics on firm's financial performance.

Erhardt et al. (2003) examine the relationship between board gender diversity and financial performance. Their results show that board gender diversity is positively related to profitability. Bertrand and Schoar (2003) and Xuan (2009) provide evidence that CEO and other top managers have large person-specific heterogeneity in their management styles, and these person-specific styles explain a substantial portion of the variations in firms' capital structures, investment decisions and organizational structures. Barker and Mueller (2002) study how R\&D expenditures of firms, as compared to industry competitors, vary with the characteristics of their CEOs. They conclude that CEO characteristics explain a significant proportion of the variance in R\&D spending among firms. Daboub et al. (1995) analyze the relationships between management characteristics and the firm's illegal activity. They contend that management characteristics, such as engineering work experience, age, and formal business education, are associated with the firm's illegal activity.

\subsection{Audit Committee and Earnings Management}

Earnings management is a well-documented accounting phenomenon. Healy and Wahlen (1999) define occurrence of earnings management as when managers use judgment in financial reporting or structure transactions to misrepresent the underlying economic performance of a company or to influence contractual outcomes that depend on reported accounting numbers. China's listed firms have many specific incentives to engage in earnings management, such as the incentive to avoid being special treated (ST) or particular treated (PT), ${ }^{4}$ the incentive to stock rights offering, and the incentive to seasoned equity offering, ${ }^{5}$ etc. Chen and Yuan (2004) investigate the association between earnings management and capital resource allocation, and they find that China's listed firms engage in earnings management to satisfy the requirements of seasoned equity offerings policy. Haw et al. (2005) examine whether Chinese listed firms manage earnings to meet regulatory benchmarks, and they find that managers execute transactions involving below-the-line items and use income-increasing accounting accruals to meet regulatory ROE targets for stock rights offerings. Chen et al. (2008) investigate whether Chinese local governments help listed companies in their jurisdictions to engage in earnings management. The evidence shows that local governments provide subsidies to help listed firms boost their earnings above the regulatory threshold of rights offering and delisting.

Previous research has documented that many factors can affect earnings management, such as auditor quality, board characteristics, media coverage, analyst coverage, and institutional monitoring, etc. Yu (2008) documents that equity analyst coverage can influence managers' earnings management decision. Chung et al. (2002) indicate that institutional monitoring also can work as a watchdog for earnings management. Becker et al. (1998) and Jenkins and Velury (2008) examine whether auditor quality has an effect on earnings management. They find evidence that high quality auditor can decrease earnings management. Finally, Lin and Hwang (2010) in a

\footnotetext{
${ }^{4}$ The delisting policy was issued by CSRC in 1998, which included Special Treatment (ST) policy and Particular Transfer (PT) policy. The ST policy required all of the listed companies with two successive years of loss will be special treated. The particular transfer (PT) policy required any listed companies with loss for three consecutive years be designated as a PT company. Being ST or PT will bring great difficulties to the firm's operation.

${ }^{5}$ There are two ways for Chinese listed firms to equity refinancing: rights offering (RO) and seasonal equity offering (SEO). China Securities Regulation Commission (CSRC) require that listed firms' ROE must greater than 6\% in three successive years, then it can rights offering. CSRS also require that listed firms' ROE must greater than $10 \%$ in three successive years, and then it can seasonal equity offering. The primary source of additional financing for listed firms in China's stock exchanges is equity refinancing (Chen et al., 2008).
}

(C) 2012 The Clute Institute http://www.cluteinstitute.com/ 
comprehensive meta-analysis find significant associations between earnings quality and various measures of corporate governance effectiveness and audit quality.

A growing body of literature begins to focus on the effects of audit committee characteristics on earnings management. Klein (2002) finds that the independence of audit committee is negatively related to earnings management. Xie et al. (2003), Yang and Krishnan (2005) document that the frequency of audit committee meeting is negatively related to current discretionary accruals. Abbott et al. (2004) find the independence and meeting frequency of the audit committee exhibit a significant and negative association with the occurrence of restatement. Anderson et al. (2004) and Lin et al. (2006) find that audit committee size, independence, and meeting frequency are positively related to the quality of corporate financial reporting.

\subsection{Hypothesis Development}

Hambrick and Mason (1984) and Carpenter et al. (2004) argue that management cognitions, values, and perceptions may predict organizational outcomes such as strategic choices and performance, commonly referred to as Upper Echelons Theory. They believe that characteristics of top management, such as age, gender, work experience, and education, are reasonable proxies for underlying differences in their cognitions, values, and perceptions. Therefore, the central tenets of audit committees' personal characteristics affecting corporate earnings management are that (1) the effort to monitor earnings management behavior is reflection of the values and cognitive bases of audit committees, (2) the values and cognitive bases of audit committees are a function of their observable characteristics such as age, gender, education, work experience, and (3) as a result, significant financial reporting quality will be associated with the observable characteristics of audit committees.

In the aforementioned discussions, audit committees' personal characteristics have the potential to affect firm's earnings management behavior. Therefore, we believe that the following characteristics of audit committees in Chinese listed firms have the potential to affect firm's earnings management behavior.

Age: An individual's age is expected to influence strategic decision-making perspectives and choices (Wiersema and Bantel, 1992). The management's age can be viewed both as a proxy for the extent of experience and as a signal of his or her resistance to risk-taking and change (Escriba-Esteve et al., 2009). Older audit committees may have less physical and mental stamina or may be less able to grasp new ideas and have a limited capacity for dealing with challenging situations. These attributes in turn may explain the adoption of a more conservative stance (Hambrick and Mason, 1984; MacCrimmon and Wehrung, 1986; Herrmann and Datta, 2006).

Furthermore, the financial and career security may be more important to older executives (Wiersema and Bantel, 1992). Their social circles, spending traits and expectations about retirement income are well established. Any risky actions that might disrupt these well-established attributes generally are avoided. Older audit committees may be more conservative than younger audit committees when choosing external auditors, and may spend more effort to prevent the collusion between external auditors and managers. Furthermore, older audit committees may have more experience than younger audit committees, which may help them to find out the weaknesses of internal control easier. The above discussions lead to the following hypothesis:

H1: Audit committees' age is negatively related to earnings management.

Gender: It has been long acknowledged in cognitive psychology and management literature that significant gender differences exist in conservatism, risk averseness, and ethical behavior (Bernardi and Arnold, 1997; Sunden and Surette, 1998; Schubert, 2006). A considerable body of economic psychology literature examines the effects of female executives and directors on the firm's financial performance and market value (Carter et al. 2003; Erhardt et al. 2003; Farrell and Hersch, 2005; Campbell and Minguez-Vera, 2008). ${ }^{6}$ For example, Erhardt et al. (2003) find that the diversity of the board is positively associated with profitability. They reason that gender diversity may lead

\footnotetext{
${ }^{6}$ The famous think tank 'catalyst' conducts a study in 2010, they re-ranking the 'Fortune' 500 companies according to the proportion of women in the board of director, and they found that the ROA of the top $25 \%$ ranked companies is $53 \%$ higher than companies that ranked in the final $25 \%$.
} 
to a wider knowledge base, which may create a competitive advantage compared to companies with non-diversified boards. Similarly, Carter et al. (2003), Farrell and Hersch (2005), and Campbell and Minguez-Vera (2008) find that gender diversity is associated with improved financial performance and higher firm value. Heminway (2007) argues that women are more trustworthy than men, and are thereby less likely to manipulate corporate financial and other disclosures. Peni and Vahamaa (2010) provide evidence that female CFOs engage in less earnings management than male CFOs. Female audit committees may be more conservative than male audit committees, and they may also have higher ethical level than male audit committees. These attributes make them to choose more effective external auditors. In addition, female audit committees may be more earnest than male audit committees, which may ensure firm has more soundness internal control system. So we hypothesize:

H2: The gender diversity of audit committee is negatively associated with earnings management.

Working experience: A stream of research has discussed the influence of an executive's career path and life experience on his or her decision making. Started by Dearborn and Simon (1958), this line of research suggests that experience with the goals, rewards, and methods of a particular functional area causes managers to perceive and interpret information in ways that suit and reinforce their functional training. Malmendier et al. (2011) find that the experience of Great Depression affects CEOs' financing decision, and the military experience can make CEOs more aggressive. Malmendier and Nagel (2011) find that CEOs who have the experiences of macroeconomic shocks are less likely to take financial risk.

Xie et al. (2003) suggest that the members on audit committee with financial background or working experience can better understand earnings management behavior relative to those without such background or experience. Chinese Sarbanes-Oxley Act requires that audit committees include at least one "financial expert". Abbott et al. (2004) find that there is a significant negative association between an audit committee that includes at one member with financial expertise and restatement. Similarly, we argue that audit committees with financial working experience are more familiar with the process of financial reporting and they are more easily to find earnings management behavior. Therefore, based on the above discussions, we hypothesize that:

H3: The proportion of audit committees that have financial working experience is negatively associated with earnings management.

Educational level: Level of education reflects an individual's cognitive ability and skills (Wiersema and Bantel, 1992). Executives with a higher level of education are able to make better quality decisions because of their higher cognitive abilities to process and analyze information (Hitt and Tyler, 1991; Wiersema and Bantel, 1992; Wally and Baum, 1994; Papadakis and Barwise, 2002). They can also discriminate better between extensive varieties of alternatives to understand organizational problems (Wiersema and Bantel, 1992; Herrmann and Datta, 2005). Therefore, they are able to devise more appropriate strategies when facing earnings management dilemma. Following this line of reasoning, we argue that better educated audit committees may have greater understanding of earnings management strategies relative to their less educated counterparts. Therefore, we formulate the following hypothesis:

H4: The average education level of audit committees is negatively associated with earnings management.

\section{EMPIRICAL METHODOLOGIES}

\subsection{Sample Selection and Data Sources}

The initial sample used in this paper consists of all China's A-share list firms from 2004 to 2010. We restrict our sample to nonfinancial firms with requisite data and with positive book value. We also exclude firms without audit committee. The final sample consists of 8,148 firm-year observations. All the financial data used in this research come from the GATA database and the audit committees' personal characteristics data are collected from annual reports of sample firms. 


\subsection{Measurement of Variables}

\subsubsection{Measurement of Earnings Management}

Discretionary accruals have been used frequently as the measurement of earnings management in prior studies (Defond and Jiambalvo, 1994; Healy and Wahlen, 1999; Dechow et al., 2010). Previous studies of Chinese listed firms have documented that discretionary accruals can also be used as a measurement of earnings management (e.g., Chen and Wang, 2007; Haw et al., 2005). To measure accrual-based earnings management, we employ the cross-sectional version of the modified Jones (1991) model as presented by Defond and Jiambalvo (1994). Consistent with prior literature, we define total accrual as the difference between net income before extraordinary items and cash flows from operations. We regress total accrual on the change in sales and the level of property, plant and equipment by year using all firms in the same 2-digit SIC code as follows:

$\frac{T A C_{i t}}{A_{i t-1}}=\alpha_{1}\left(\frac{1}{A_{i t-1}}\right)+\alpha_{2}\left(\frac{\Delta R E V_{i t}}{A_{i t-1}}\right)+\alpha_{3}\left(\frac{P P E_{i t}}{A_{i t-1}}\right)+\boldsymbol{\varepsilon}_{i t}$

where $T A C_{i t}$ is total accrual for firm $\mathrm{i}$ in year $\mathrm{t}, A_{i t}$ is total assets for firm i in year $\mathrm{t}, \triangle R E V_{i t}$ is the change in sales between year $\mathrm{t}-1$ and year $\mathrm{t}$ for firm $\mathrm{i}$, and $P P E_{i t}$ is the property, plant, and equipment for firm i in year $\mathrm{t}$. Nondiscretionary accrual $(N D A)$ is calculated using the regression coefficients from equation (1), and the change in sales is modified by subtracting the changes in account receivables $\left(\triangle R E C_{i t}\right)$, as used in Dechow et al. (1995):

$\frac{N D A_{i t}}{A_{i t-1}}=\alpha_{1}\left(\frac{1}{A_{i t-1}}\right)+\alpha_{2}\left\lceil\left(\Delta R E V_{i t}-\triangle R E C_{i t}\right) / A_{i t-1}\right\rceil+\alpha_{3}\left(\frac{P P E_{i t}}{A_{i t-1}}\right)$

We then calculate discretionary accrual $(D A)$ as the residual:

$\frac{D A_{i t}}{A_{i t-1}}=\frac{T A C_{i t}}{A_{i t-1}}-\frac{N D A_{i t}}{A_{i t-1}}$

In this paper, we use absolute discretional accrual $\left(A B_{-} D A\right)$ as the proxy for earnings management. Following Kothari et al. (2005), this paper also uses performance matched discretionary accrual as the measure of earnings management.

\subsubsection{Measurement of Audit Committees' Personal Characteristics}

We collect audit committees' personal characteristics from the annual financial report of each firm. For each firm, we obtain a profile of audit committee from the "profile of Directors and Senior Managers" section of the firm's financial report. In addition to audit committees' names, the profile typically contains information on age, gender, education, professional background, and employment history. We use the natural logarithm of audit committees' age as the proxy of $A G E$. We use the proportion of female audit committees in audit committee $(G E N D E R)$ as the proxy for gender diversity. The proportion of audit committees with financial working experience in audit committee $(F I N B)$ is used as the proxy for financial working experience. We divide education into five levels: high school diploma, associate degree, undergraduate degree, master's degree, and doctoral degree. The education level equals 1 if audit committees have a high school diploma, and the education level equals 2 if audit committees have associate degree, and so on. We use the average education level of audit committees (EDUCA) as the proxy for education.

\subsection{Research Design}

Dechow and Dichev (2002) and Francis (2004) argue that a firm's specific financial and operating characteristics can affect its earnings quality. Therefore, we control for some of these characteristics that are shown to impact earnings management, such as firm size, leverage, book to market value, operating loss, and sales growth. We also control for audit committee size, independence, and meeting frequency, which may affect earnings management documented by previous research. In addition, considering that the macroeconomic environment and the industry conditions may affect a firm's earnings management behavior, we also control for the year and industry 
in this paper. We use the following equations to estimate the impact of audit committees' personal characteristics on earnings management:

$$
\begin{aligned}
& A B B_{-} D A_{t}=\alpha_{0}+\alpha_{1} A G E+\alpha_{2} \text { GENDER }+\alpha_{3} E U D C A+\alpha_{4} F I N B+\alpha_{5} \text { FSIZE }_{t} \\
& +\alpha_{6} B M_{t}+\alpha_{7} \text { LOSS }_{t}+\alpha_{8} L E V_{t}+\alpha_{9} S G_{t}+\alpha_{10} \text { ASIZE }_{t}+\alpha_{11} \text { INDEP }_{t} \\
& +\alpha_{12} \text { FREQ }_{t}+\sum_{i=1}^{m} \alpha_{13 i} I N D_{i}+\sum_{j=1}^{n} \alpha_{14 i} \text { YEAR }_{j}+\varepsilon_{t}
\end{aligned}
$$

$A G E$ is the natural logarithm of audit committees' age. GENDER is the proportion of female audit committees in audit committee. EUDCA is the average education level of audit committees. FINB is the proportion of audit committees who have financial working experience in audit committee. FSIZE $E_{t}$ is the logarithm of a firm's total assets in year t. $B M_{t}$ is a firm's book to market value in year t. $L O S S_{t}$ is a dummy variable equal to 1 when a firm reports net loss in year $\mathrm{t}$, and 0 otherwise. $L E V_{t}$ is firm leverage in year $\mathrm{t}$, measured as the ratio of total liability to net assets. $S G_{t}$ is sales growth in year t. $A S I Z E_{t}$ is the number of members in audit committee in year t. $I N D E P_{t}$ is the proportion of independent audit committees in audit committee in year t. $F R E Q_{t}$ is the number of audit committee meetings in year t. $I N D_{i}$ is a dummy equal to 1 when a firm belongs to industry i, and 0 otherwise. $Y E A R_{j}$ is a dummy equal to 1 when the year is $j$, and 0 otherwise. The definition and measurement of variables are summarized in Table 1:

Table 1: Definition and Measurement of Variables

\begin{tabular}{ll}
\hline Variable & \\
\hline$A B \_D A$ & Absolute discretionary accruals, calculated using modified Jones model as presented in equation (3). \\
$A G E$ & Age, the average age of audit committees. \\
$G E N D E R$ & Gender, the ratio of female members in audit committee. \\
$E D U C A$ & Education level, the average education level of audit committees. \\
$F I N B$ & Financial working experience, the proportion of members that have financial working experience in audit \\
& committee. \\
$F S I Z E$ & Firm size, the natural logarithm of a firm's total assets. \\
$B M$ & Book to market ratio, the book value of asset to firm's market value. \\
$L O S S$ & Dummy variable, which equals 1 when a firm report net loss in year t and 0 otherwise. \\
$L E V$ & Financial leverage, firm's total liability to net assets. \\
$S G$ & Sales growth rate from year t-1 to year t. \\
$A S I Z E$ & Audit committee size, the number of members in audit committee \\
$I N D E P$ & Audit committee independence, the proportion of independent audit committees in audit committee. \\
$F R E Q$ & Meeting frequency, the number of meetings of audit committee in a year. \\
\hline
\end{tabular}

\subsection{Summary Statistics and Correlations}

Table 2 displays the descriptive statistics of variables used in this paper. The mean of absolute discretional accruals $\left(A B \_D A\right)$ is 0.110 and the median of $A B \_D A$ is 0.069 . The average of $A G E$ is 3.784 , and the median $A G E$ is 3.785. The average proportion of female members in audit committee (GENDER) is 0.110 , indicating that it is difficult for females to be the member of audit committee in China. The average education level of audit committees $(E D U C A)$ is 3.575, indicating that most of the members in audit committee have an undergraduate or higher degree. The average proportion of members who have financial working experience in audit committee $(F I N B)$ is 0.159 . The average size of audit committee (ASIZE) is 4.148 , indicating that there are 4 or more members in audit committee in China's listed firms. The average proportion of independent committees (INDEP) is 0.642 , indicating that there are more than one third of audit committees are not independent. The average meeting frequency $(F R E Q)$ is 9.533 , indicating that audit committees meet about 10 times in a year in China's listed firms. 
Table 2: Descriptive Statistics of Variables

\begin{tabular}{|c|c|c|c|c|c|c|}
\hline Variables & Obs & Mean & Std.dv & Min & Median & Max \\
\hline$A B \_D A$ & 8148 & 0.110 & 0.153 & 0.000 & 0.069 & 1.100 \\
\hline$A \bar{G} \bar{E}$ & 8148 & 3.784 & 0.348 & 3.020 & 3.785 & 4.159 \\
\hline GENDER & 8148 & 0.110 & 0.159 & 0.000 & 0.107 & 0.667 \\
\hline$E D U C A$ & 8148 & 3.575 & 1.498 & 3.000 & 3.286 & 5.000 \\
\hline$F I N B$ & 8148 & 0.429 & 0.285 & 0.333 & 0.504 & 1.000 \\
\hline FSIZE & 8148 & 21.241 & 1.143 & 12.321 & 21.143 & 27.818 \\
\hline$B M$ & 8148 & 0.748 & 0.275 & 0.028 & 0.769 & 5.540 \\
\hline LOSS & 8148 & 0.145 & 0.350 & 0.000 & 0.000 & 1.000 \\
\hline$L E V$ & 8148 & 1.217 & 0.964 & 0.120 & 0.965 & 3.906 \\
\hline$S G$ & 8148 & 0.067 & 0.286 & -0.731 & 0.115 & 0.530 \\
\hline$A S I Z E$ & 8148 & 4.148 & 2.407 & 3.000 & 4.000 & 7.000 \\
\hline INDEP & 8148 & 0.642 & 0.389 & 0.333 & 0.630 & 1.000 \\
\hline FREQ & 8148 & 9.533 & 4.862 & 2.000 & 9.000 & 49.000 \\
\hline
\end{tabular}

Note: Please see Table 1 for the definitions and measurement of variables.

Table 3 presents the Pearson product-moment correlations between variables. The correlation between $A B \_D A$ and $A G E, G E N D E R, F I N B$ are negative and significant. The correlations between $A B \_D A$ and $E D U C A$ is positive and but not significant. The directions of most correlations are consisting with the hypothesis. Vast majority of the correlations are between -0.20 and 0.20 . The highest Pearson correlation between LOSS and SG is -0.324 . The correlations do not indicate any serious collinearity problem. Thus, the variables included in our regression models capture distinct features of the impact of audit committees' personal characteristics on earnings management.

\section{EMPIRICAL RESULTS}

Table 4 presents the regression results of the impact of audit committees' personal characteristics on earnings management. To check the robustness of results, we use both discretionary accrual based on the modified Jones (1991) model and performance matched discretionary accrual based on Kothari et al. (2005) as the measurements of earnings management. Also, we use both cross-sectional regression and fixed-two-way model based on panel data to estimate the impact of audit committees' personal characteristics on earnings management. Table 4, column (1) displays the regression results using discretionary accrual as the dependent variable, and column (2) displays the regression results using performance matched discretionary accrual as the dependent variable.

As presented in Table 4, the coefficients of $A G E$ in cross-sectional regressions are negative and significant at the $1 \%$ level for both accrual models (coefficient=-0.021 and $-0.028 ; \mathrm{t}=-4.74$ and -4.79 , respectively), indicating that older audit committees may be considering more about their career security, and they may work harder to prevent firm's earnings management behavior, providing support for hypothesis H1. The coefficients of GENDER in the cross-sectional regressions are negative and significant at the $1 \%$ level for both accrual models (coefficient=0.017 and $-0.012 ; \mathrm{t}=-2.43$ and -4.86 , respectively), supporting hypothesis $\mathrm{H} 2$. These results suggest that female audit committees are related to less earnings management than their male counterparts, consistent with Peni and Vahamaa (2010), who provide evidence that female CFOs engage in less earnings management via accruals than male CFOs. The reason may be that female managers are more conservative and have higher ethical level than male managers, and they cannot bear earnings management behavior occurs in the firm which they are serving. The coefficients of FINB in cross-sectional regressions are positive and significant at the $1 \%$ level for both accrual models (coefficient $=0.034$ and $0.027 ; \mathrm{t}=4.61$ and 3.60 , respectively). The results indicate that audit committees with financial working experience may be easier to perceive earnings management, so that they can prevent earnings management more effective than audit committees without financial working experience, supporting hypothesis $\mathrm{H} 3$. The coefficients of EDUCA in the cross-sectional regressions are positive but not significant for both accrual models (coefficient $=0.012$ and $0.009 ; \mathrm{t}=1.59$ and 0.98 , respectively). These results provide evidence that audit committees with higher education cannot insure them to become the effective monitor.

We also run fixed-two-way regression models based on panel data. The results, as presented in Table 4 columns (3) and (4), are essentially the same as those in cross-sectional models using pooled data discussed above. The similar results indicate that the results are robust. 


\begin{tabular}{|c|c|c|c|c|c|c|c|c|c|c|c|c|c|}
\hline Variables & $A B \_D A$ & $A G E$ & GENDER & $E D U C A$ & $F I N B$ & FSIZE & $B M$ & LOSS & $L E V$ & $S G$ & ASIZE & INDEP & FREQ \\
\hline$A B \_D A$ & 1.000 & & & & & & & & & & & & \\
\hline$A G E$ & $-0.065^{* * * *}$ & 1.000 & & & & & & & & & & & \\
\hline GENDER & $-0.038^{* * * *}$ & $-0.061^{* * * *}$ & 1.000 & & & & & & & & & & \\
\hline$E D U C A$ & 0.011 & $-0.017^{*}$ & -0.008 & 1.000 & & & & & & & & & \\
\hline FINB & $-0.063^{* * * *}$ & $-0.071^{* * * *}$ & $0.053^{* * *}$ & $0.126^{* * * *}$ & 1.000 & & & & & & & & \\
\hline FSIZE & $-0.069^{* * *}$ & $0.105^{* * *}$ & $-0.032^{* * * *}$ & $0.041^{* * *}$ & $0.020^{* *}$ & 1.000 & & & & & & & \\
\hline$B M$ & $-0.078^{* * * *}$ & $0.050^{* * *}$ & $-0.017^{*}$ & $0.060^{* * *}$ & $0.092^{* * *}$ & $0.197^{* * *}$ & 1.000 & & & & & & \\
\hline LOSS & $0.101^{* * * *}$ & $-0.045^{* * *}$ & 0.011 & -0.006 & $-0.049^{* * * *}$ & $-0.091^{* * *}$ & 0.007 & 1.000 & & & & & \\
\hline$L E V$ & $0.020^{* *}$ & -0.009 & $0.020^{* *}$ & -0.005 & $0.037^{* * *}$ & $0.241^{* * *}$ & $0.106^{* * * *}$ & $0.071^{* * *}$ & 1.000 & & & & \\
\hline$S G$ & $-0.048^{* * *}$ & -0.005 & $-0.022^{* *}$ & $0.023^{* *}$ & $-0.018^{*}$ & $0.083^{* * *}$ & $0.054^{* * * *}$ & $-0.324^{* * *}$ & -0.011 & 1.000 & & & \\
\hline$A S I Z E$ & $-0.085^{* * *}$ & $0.022^{* * *}$ & 0.008 & $0.020^{* *}$ & $0.031^{* * *}$ & $0.257^{* * * *}$ & $0.106^{* * *}$ & $-0.059^{* * *}$ & $-0.073^{* * *}$ & -0.007 & 1.000 & & \\
\hline INDEP & $-0.056^{* * *}$ & 0.015 & 0.011 & -0.013 & $0.027^{* * *}$ & $0.029^{* * *}$ & $0.064^{* * *}$ & $-0.038^{* * *}$ & $-0.021^{* *}$ & -0.012 & $0.030^{* * * *}$ & 1.000 & \\
\hline FREQ & $-0.102^{* * * *}$ & 0.013 & 0.009 & $0.026^{* * *}$ & $0.020^{* *}$ & $0.032^{* * * *}$ & $0.077^{* * * *}$ & $-0.042^{* * *}$ & $-0.054^{* * *}$ & $0.023^{* *}$ & $0.041^{* * * *}$ & $0.082^{* * *}$ & 1.000 \\
\hline
\end{tabular}

1. This table presents the Pearson product-moment correlations.

2. $\quad * * *, * *, *$ Indicate significance at the $0.01,0.05$, and 0.10 levels or better, respectively

3. Please see Table 1 for the definitions and measurement of variables. 
Meanwhile, several control variables are worth mentioning. First, the coefficients of $B M$ in all models are negative and significant as expected. Second, the coefficients of $S G$ are positive and significant using panel data (and positive but not significant using pooled data). The results provide some evidence that firms with growth opportunity have more incentives to manipulate earnings, consistent with Skinner and Sloan (2002). Third, the coefficients of $L E V$ and $L O S S$ are positive and significant as expected, suggesting that firms with higher debt level and poorer performance are more likely to engage in earnings management, consistent with Dichev and Skinner (2002). The coefficients of FSIZE are negative and significant as expected, which indicate that large firms engage in less earnings management relative to small firms. The coefficients of ASIZE, INDEP, and FREQ are negative and significant, indicating that larger audit committee, higher independent, and higher frequency of audit meeting can deter firms from managing earnings.

Table 4: Regression of Earnings Management on Audit Committees' Personal Characteristics

\begin{tabular}{|c|c|c|c|c|}
\hline \multirow[b]{2}{*}{ Variable } & \multicolumn{2}{|c|}{ Pooled Regression } & \multicolumn{2}{|c|}{ Panel Regression } \\
\hline & (1) & (2) & (3) & (4) \\
\hline Intercept & $0.315^{* * * * *}(11.38)$ & $0.324^{* * * * *}(10.29)$ & $0.283^{* * * * *}(27.21)$ & $0.259^{* * 3 *}(15.35)$ \\
\hline$A G E$ & $-0.021^{* * * *}(-4.74)$ & $-0.028^{* * * *}(-4.79)$ & $-0.016^{* * *}(-3.48)$ & $-0.017^{* * *}(-3.27)$ \\
\hline GENDER & $-0.017^{* *}(-2.43)$ & $-0.012^{* * *}(-4.86)$ & $-0.007^{* * *}(-4.45)$ & $-0.004^{* * *}(-3.55)$ \\
\hline$E D U C A$ & $0.012(1.59)$ & $0.009(0.98)$ & 0.007 (0.67) & $0.006(0.54)$ \\
\hline FINB & $0.034^{* * * *}(4.61)$ & $0.027^{* * * * *}(3.60)$ & $0.016^{* *}(2.39)$ & $0.017^{* *}(2.47)$ \\
\hline FSIZE & $-0.013^{* * *}(-7.55)$ & $-0.011^{* * * *}(-6.57)$ & $-0.007^{* * *}(-3.69)$ & $-0.008^{* * *}(-3.84)$ \\
\hline$B M$ & $-0.043^{* * *}(-6.70)$ & $-0.035^{* * *}(-5.04)$ & $-0.010^{* *}(-2.45)$ & $-0.007^{* *}(-2.36)$ \\
\hline LOSS & $0.036^{* * *}(9.04)$ & $0.029^{* * * *}(6.25)$ & $0.015^{* * * *}(4.79)$ & $0.009^{* * *}(3.24)$ \\
\hline$L E V$ & $0.006^{* * *}(3.23)$ & $0.004^{* *}(2.49)$ & $0.004^{* *}(2.46)$ & $0.003^{* *}(2.29)$ \\
\hline$S G$ & $0.001(0.32)$ & $0.003(0.62)$ & $0.018^{* * *}(4.95)$ & $0.023^{* * *}(6.33)$ \\
\hline ASIZE & $-0.059^{* * * *}(-3.71)$ & $-0.054^{* * * *}(-3.09)$ & $-0.026^{* * *}(-3.48)$ & $-0.29^{* * *}(-3.83)$ \\
\hline INDEP & $-0.048^{* * *}(-4.26)$ & $-0.045^{* * * *}(-3.96)$ & $-0.019^{* * *}(-3.57)$ & $-0.23^{* * *}(-3.88)$ \\
\hline$F R E Q$ & $-0.027^{* * * *}(-6.93)$ & $-0.31^{* * * *}(-7.48)$ & $-0.017^{* * *}(-6.54)$ & $-0.019^{* * *}(-6.76)$ \\
\hline Firm effect & No & No & Fixed & Fixed \\
\hline Industry effect & Dummy & Dummy & No & No \\
\hline Year effect & Dummy & Dummy & No & No \\
\hline$R$-square & 0.147 & 0.138 & 0.215 & 0.204 \\
\hline$N$ & 8,148 & 8,148 & 8,148 & 8,148 \\
\hline
\end{tabular}

Notes:

1. In order to eliminate the impact of outliers, we do the $1 \%(99 \%)$ winsorization to the data.

2. The sample used in cross-sectional regression and the panel regression is 8,148 firm-years.

3. Statistics significance at the $1 \%, 5 \%$, and $10 \%$ levels are indicated by $* * *, * *, *$, respectively (two-tail).

4. Please see Table 1 for the definitions and measurement of variables.

\section{CONCLUSIONS}

This paper investigates the role of audit committees' personal characteristics in deterring firm's earnings management behavior using a sample of Chinese A-share listed firms from 2004 to 2010. The results indicate that older audit committees can work more effectively to prevent earnings management than younger audit committees, and that female audit committees are more effective than male audit committees. The results also indicate that audit committees with financial working experience can monitor corporate earnings management effectively than those without such working experience. But we do not find that audit committees with higher education level can work as effective monitors than those with lower education level.

These results are similar using various regression models and pooled or panel data. Thus, the results reported in this paper are robust with respect to different model specifications and sample data. Overall, the findings in this paper suggest that several of audit committees' personal characteristics can affect earnings management, which in turn may affect the quality of financial accounting information.

This paper contributes existing literature by investigating the impact of audit committee on earnings management from a new perspective: audit committees' personal characteristics. We provide considerable evidence on the relationships between audit committee's personal inherent characteristics and acquired attributes and corporate earnings management behavior. 
The results of this paper have implications for investors in understanding the role of audit committees' personal characteristics in earnings management in the context of Chinese emerging capital market and socialist market economy. Moreover, the findings of this paper may have implications for regulators in promoting financial reporting quality. This paper finds that audit committees with financial working experience vis-à-vis those without such experience are more effectively in monitoring earnings management. Therefore, it may provide evidence to some regulations which require that audit committees include at least one "financial expert". Also, the findings suggest the positive role that female audit committees play in achieving greater earnings. This evidence may lend support to legislative or regulatory efforts in many countries to increase proportion of women on the board of directors.

Future research may examine the effect of other audit committees' personal characteristics on earnings management behavior, such as college degree majors. Different majors may affect the way of thinking and decision making, which in turn may affect their choice of earnings management strategies. This may have effect similar to that of financial working experience on earnings management as discussed above. Finally, the findings also may provide insights to those who are responsible for selecting and developing upper-level executives.

\section{AUTHOR INFORMATION}

Baolei Qi, a PHD candidate in School of Management, Xi'an Jiaotong University, P.R. China, and his major is accounting. Baolei Qi was a visiting scholar in Hong Kong Polytechnic University from August 2010 to May 2011. From Sep 2011 to now, Baolei Qi is a visiting scholar in University of Wisconsin-Eau Claire. E-mail: qib@uwec.edu; baoleiqi@126.com

Gaoliang Tian, an accounting professor in School of Management, Xi'an Jiaotong University, P.R. China. E-mail: tian-gl@mail.xjtu.edu.cn (Corresponding author)

\section{REFERENCES}

1. Abbott, L.J., Parker, S. and Peters, G.F. (2004). Audit Committee Characteristics and Restatement. Auditing: A Journal of Practice \& Theory, 23 (1): 69-87.

2. Anderson, R.C., Mansi, S.A., and Reeb, D.M. (2004). Board Characteristics, Accounting Report Integrity, and the Cost of Debt. Journal of Accounting and Economics 37 (3): 315-342.

3. Barker, V.L., and Mueller, G.C. (2002). CEO Characteristics and Firm R\&D Spending. Management Science 48: 782-801.

4. Becker, L., DeFond, M., Jiambalvo, J. and Subramanyam, K. (1998). The Effect of Audit Quality on Earnings Management. Contemporary Accounting Research 15: 1-24.

5. Bernardi, R. and Arnold, D. (1997). An Examination of Moral Development within Public Accounting by Gender, Staff Level, and Firm. Contemporary Accounting Research 14: 653-668.

6. Bertrand, M. and Schoar, A. (2003). Managing with style: The Effect of Managers on Firm Policies. The Quarterly Journal of Economics, 118: 1169-1208.

7. Byrnes, J., Miller, D. and Schafer, W. (1999). Gender Differences in Risk Taking: a Meta-analysis. Psychological Bulletin, 25: 367-383.

8. Campbell, K. and Minguez-Vera, A. (2008). Gender Diversity in the Boardroom and Firm Financial Performance. Journal of Business Ethics, 83: 435-451.

9. Carpenter, M.A., Geletkanycz, M.A. and Sanders, W.G. (2004). Upper Echelons Research Revisited: Antecedents Elements, and Consequences of Top Management Team Composition. Journal of Management, 30: 749-778.

10. Carter, D., Simkins, B. and Simpson, W. (2003). Corporate Governance, Board Diversity, and Firm Value. The Financial Review, 38: 33-53.

11. Chen K.C.W, and Yuan, H. (2004). Earnings Management and Capital Resource Allocation: Evidence from China's Accounting-Based Regulation of Rights Issues. The Accounting Review, 79: 645-665.

12. Chen, K.C.W, and Wang, J. (2007). Accounting-Based Regulation in Emerging Markets: The Case of China's Seasoned-Equity Offerings. International Journal of Accounting Review, 42: 221-236. 
13. Chen. X, Lee, C-W.J. and Li, J. (2008). Government Assisted Earnings Management in Chin. Journal of Accounting and Public Policy, 27: 262-274.

14. Chung, R., Firth, M. and Kim, J.B. (2002). Institutional Monitoring and Opportunistic Earnings Management. Journal of Corporate Finance, 8: 29-48.

15. Daboub, A. J., Rasheed, AM. A., Priem, R.M. and Gray, D.A. (1995). Top Management Team Characteristics and Corporate Illegal Activity. The Academic of Management Review, 20: 138-170.

16. Dearborn, C. and Simon, H.A. (1958). Selective perception: A note on the department identifications of executives. Sociometry, 21: 140-144.

17. Dechow, P. and Dichev, I. (2002). The Quality of Accruals and Earnings: The Role of Accrual Estimation Errors. The Accounting Review, 77: 35-59.

18. Dechow, P., Ge, W. and Schrand, C. (2010). Understanding Earnings Quality: A Review of the Proxies, Their Determinants and Their Consequences. Journal of Accounting and Economics, 50: 344-401.

19. Dechow, P., Sloan, R. and Sweeney, A. (1995). Detecting Earnings Management. The Accounting Review, 70: 193-225.

20. DeFond, M.L., and Jiambalvo, J. (1994). Debt Covenant Violation and Manipulation of Accruals. Journal of Accounting and Economics, 17: 145-176.

21. Dichev, I., and Skinner, D.J. (2002). Large-Sample Evidence on the Debt Covenant Hypothesis. Journal of Accounting Research, 40:1091-1123.

22. Erhardt, N., Werbel, J. and Shrader, C. (2003). Board of Director Diversity and Firm Financial Performance. Corporate Governance: An International Review, 11: 102-111.

23. Escriba-Esteve, A., Sanchez-Peinado, L. and Sanchez-Peinado, E. (2009). The influence of top management teams in the strategic orientation and performance of small and medium-sized enterprises. British Journal of Management, 20: 581-597.

24. Farrell, K., and Hersch, P. (2005). Additions to Corporate Boards: the Effect of Gender. Journal of Corporate Finance, 11: 85-106.

25. Francis, J., LaFond, R., Olsson, P. and Schipper, K. (2004). Cost of Equity and Earnings Attributes. The Accounting Review, 79: 967-1010.

26. Hambrick, D. C., and Mason, P. (1984). Upper echelons: The organization as a reflection of its top manager. Academy of Management Review, 9: 1193-206.

27. Haw, I.M., Qi, D., Wu, D. and Wu, W. (2005). Earnings Management of Listed Firms in Response to Security Regulations in China's Emerging Capital Market. Contemporary Accounting Research, 22(1): 95140.

28. Healy, P.M., and Wahlen, J.M. (1999). A Review of the Earnings Management Literature and Its Implications for Standard Setting. Accounting Horizons, 13: 365-384.

29. Heminway, J.M. (2007). Sex, Trust, and Corporate Boards. Hasting Women 's Law Journal, 18: $173-193$.

30. Herrmann, P. and Datta, D.K. (2006). CEO Experiences: Effects on the Choice of FDI Entry Mode. Journal of Management Studies, 43: 755-778.

31. Hitt, M.A., and Tyler, B.B. (1991). Strategic Decision Models: Integrating Different Perspectives. Strategic Management Journal, 12: 327-351.

32. Jenkins, D. and Velury, U. (2008). Does Auditor Tenure Influence the Reporting of Conservative Earnings? Journal of Accounting and Public Policy, 27: 115-132.

33. Jones, J.J. (1991). Earnings Management during Import Relief Investigations. Journal of Accounting Research, 29: 193-228.

34. Klein, A. (2002). Audit Committee, Board of Director Characteristics, and Earnings Management. Journal of Accounting and Economics, 33: 375-400.

35. Kothari S.P., Leone, A.J. and Wesley, C.E. (2005). Performance Matched Discretionary Accrual Measures. Journal of Accounting and Economics, 39: 163-197.

36. Lin, J.W., Li, J.F., and Yang J.S. (2006). The Effect of Audit Committee Performance on Earnings Quality. Managerial Auditing Journal, 21 (9): 921-933.

37. Lin, J.W., and Hwang, M.I., 2010. Audit Quality, Corporate Governance, and Earnings Management: A Meta-Analysis. International Journal of Auditing 14: 57-77.

38. MacCrimmon, K. R., and Wehrung, D.A. (1986). Taking Risks: The Management of Uncertainty. Administrative Science Quarterly, 33: 58-67. 
39. Malmendier, U., Tate, G. and Yan, J. (2011). Overconfidence and Early-Life Experiences: The Effect of Managerial Traits on Corporate Financial Policies. The Journal of Finance, 66: 1687-1733.

40. Malmendier, U. and Nagel, S. (2011). Depression Babies: Do macroeconomic experiences affect risk taking? The Quarterly Journal of Economics, 126: 373-416.

41. Papadakis, V. W. and Barwise, P. (2002). How Much Do CEOs and Top Managers Matter in Strategic Decision-Making? British Journal of Management, 13:83-95.

42. Peni, E., and Vahamaa, S. (2010). Female Executives and Earnings Management. Managerial Finance, 36 : 629-645.

43. Schubert, R. (2006). Analyzing and Managing Risks on the Importance of Gender Difference in Risk Attitudes. Managerial Finance, 32: 706-715.

44. Skinner, D.J., and Sloan, R.G. (2002). Earnings Surprises, Growth Expectations and Stock Returns or Don't Let an Earnings Torpedo Sink Your Portfolio. Review of Accounting Studies, 7: 289-312.

45. Sunden, A. and Surette, B. (1998). Gender Differences in the Allocation of Assets in Retirement Savings Plans. American Economic Review, 88: 207-211.

46. Wally, S., and Baum, J. (1994). Personal and Structural Determinants of the Pace of Strategic Decision Making. Academic Managerial Journal, 37: 932-956.

47. Wiersema, M.F. and Bantel, K.A. (1992). Top Management Team Demography and Corporate Strategic Change. Academy of Management Journal, 35: 91-121.

48. Xie, B, Davidson, W.N. and DaDalt, P.J. (2003). Earnings Management and Corporate Governance: The Role of the Board and the Audit Committee. Journal of Corporate Finance, 9: 295-316.

49. Xuan, Y.H. (2009). Empire Building or Bridge-Building? Evidence from New CEOs Internal Capital Market Allocation Decisions. Review of Financial Studies, 22: 4919-4948.

50. Yang, J.S. and Krishnan, J. (2005). Audit Committees and Quarterly Earnings Management. International Journal of Auditing, 9 (3): 201-219.

51. Yu, F. (2008). Analyst Coverage and Earnings Management. Journal of Financial Economics, 88: $245-271$. 
NOTES 